\title{
Endosonography with lymph node sampling for restaging the mediastinum in lung cancer: A systematic review and pooled data analysis
}

\author{
Long Jiang, MD, PhD, ${ }^{\mathrm{a}, \mathrm{b}}$ Weizhe Huang, $\mathrm{MD}, \mathrm{PhD},{ }^{\mathrm{c}}$ Jun Liu, MD, $\mathrm{PhD},{ }^{\mathrm{a}, \mathrm{b}}$ \\ Kassem Harris, MD, FCCP, ${ }^{\mathrm{d}}$ Lonny Yarmus, MD, FCCP, ${ }^{\mathrm{e}}$ Wenlong Shao, MD, PhD, ${ }^{\mathrm{a}, \mathrm{b}}$ \\ Hanzhang Chen, MD, PhD, ${ }^{\mathrm{a}, \mathrm{b}}$ Wenhua Liang, MD, PhD, ${ }^{\mathrm{a}, \mathrm{b}}$ and Jianxing He, MD, PhD, FACS, FRCS, ${ }^{\mathrm{a}, \mathrm{b}}$ on \\ behalf of the AME Lung Cancer Collaborative Group
}

\begin{abstract}
Background: Mediastinal restaging after induction treatment is still a difficult and controversial issue. We aimed to investigate the diagnostic accuracy of endobronchial ultrasound-guided transbronchial needle aspiration and endoscopic ultrasound-guided fine-needle aspiration for restaging the mediastinum after induction treatment in patients with lung cancer.
\end{abstract}

Methods: Embase and PubMed databases were searched from conception to March 2019. Data from relevant studies were analyzed to assess sensitivity and specificity of endobronchial ultrasound-guided transbronchial needle aspiration and endoscopic ultrasound-guided fine-needle aspiration, and to fit the hierarchical summary receiver operating characteristic curves.

Results: A total of 10 studies consisting of 558 patients fulfilled the inclusion criteria. All patients were restaged by endobronchial ultrasound-guided transbronchial needle aspiration, endoscopic ultrasound-guided fine-needle aspiration, or both. Negative results were confirmed by subsequent surgical approaches. There were no complications reported during any endosonography approaches reviewed. The pooled sensitivities of endobronchial ultrasound-guided transbronchial needle aspiration and endoscopic ultrasound-guided fine-needle aspiration were $65 \%$ (95\% confidence interval [CI], 52-76) and 73\% (95\% CI, 52-87), respectively, and specificities were 99\% (95\% CI, 78-100) and 99\% (95\% CI, 90-100), respectively. The area under the hierarchical summary receiver operating characteristic curves were 0.85 (95\% CI, 0.81-0.88) for endobronchial ultrasound-guided transbronchial needle aspiration and 0.99 (95\% CI, 0.98-1) for endoscopic ultrasoundguided fine-needle aspiration. Moreover, for patients who received chemotherapy alone, the pooled sensitivity of endosonography with lymph node sampling for restaging was 66\% (95\% CI, 56-75), and specificity was $100 \%$ (95\% CI, 34-100); for patients who received chemoradiotherapy, the results seemed similar with a sensitivity of $77 \%$ (95\% CI, 47-92) and specificity of $99 \%$ (95\% CI, 48-100).

Conclusions: Endosonography with lymph node sampling is an accurate and safe technique for mediastinal restaging of lung cancer. (J Thorac Cardiovasc Surg 2020;159:1099-108)

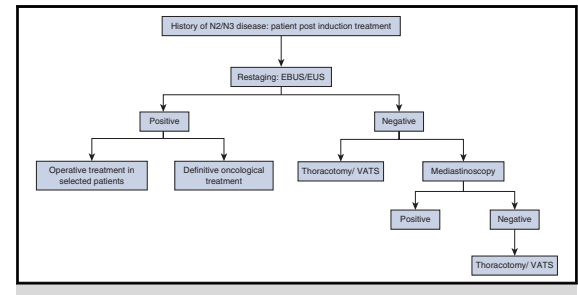

The diagram that summarizes the findings and describes a clinically reasonable pathway for NSCLC restaging.

Central Message

Endosonography with lymph node sampling is an accurate and safe technique for mediastinal restaging of lung cancer.

\section{Perspective}

Accurate mediastinal restaging of lung cancer is crucial because the stage of disease directly determines the prognosis and guides treatment options. Endosonography with lymph node sampling has been confirmed as an accurate and safe technique for mediastinal staging and restaging of lung cancer.

See Commentary on page 1109.

\footnotetext{
From the a Department of Thoracic Surgery/Oncology, First Affiliated Hospital of Guangzhou Medical University, Guangzhou, China; 'State Key Laboratory of Respiratory Disease, National Clinical Research Center for Respiratory Disease, Guangzhou Institute of Respiratory Disease, Guangzhou, China; 'Department of Thoracic Surgery, the First Affiliated Hospital, Medical College of Shantou University, Shantou, Guangdong, China; ${ }^{\mathrm{d} I n t e r v e n t i o n a l ~ P u l m o n o l o g y ~ S e c t i o n, ~ P u l-~}$ monary Critical Care Division, Department of Medicine, Westchester Medical

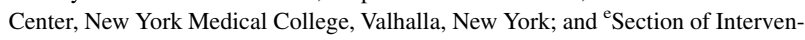
tional Pulmonology, Division of Pulmonary and Critical Care Medicine, Johns Hopkins University, Baltimore, Md.

Drs Jiang, Huang, Liu are co-first authors.
}

Received for publication Jan 19, 2019; revisions received July 17, 2019; accepted for publication July 17, 2019; available ahead of print Oct 5, 2019.

Address for reprints: Jianxing He, MD, PhD, FACS, FRCS, and Long Jiang, MD, $\mathrm{PhD}$, Department of Thoracic Surgery and Oncology, First Affiliated Hospital of Guangzhou Medical University, State Key Laboratory of Respiratory Disease, National Clinical Research Center for Respiratory Disease, Guangzhou Institute of Respiratory Disease, No. 151, Yanjiang Rd, Guangzhou, Guangdong Province, PR 510120, China (E-mail: drhe_jianxing@163.com and drjiang_long@163. com).

$0022-5223 / \$ 36.00$

Copyright (c) 2019 by The American Association for Thoracic Surgery

https://doi.org/10.1016/j.jtcvs.2019.07.095 


\section{Abbreviations and Acronyms \\ $\mathrm{CI}=$ confidence interval \\ CT $=$ computed tomography \\ EBUS-TBNA $=$ endobronchial ultrasound-guided transbronchial needle aspiration \\ EUS-FNA = endoscopic ultrasound-guided fine- needle aspiration \\ $\mathrm{LR} \quad=$ likelihood ratio \\ NSCLC $=$ non-small cell lung cancer \\ PET $=$ positron emission tomography}

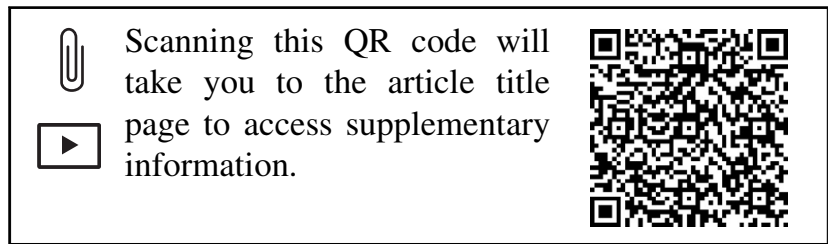

At present, the treatment for stage IIIA-N2 non-small cell lung cancer (NSCLC) is chemoradiotherapy. ${ }^{1}$ However, surgical resection may be appropriate for select patients with N2 disease, particularly for those whose disease responds to induction chemotherapy or chemoradiotherapy. Accurate restaging of the mediastinum in these patients will be of increasing importance to identify patients who have been successfully down-staged and who may benefit from subsequent surgical resection.

The effective approach for restaging is controversial and the subject of much debate. Mediastinoscopy is well established as an invasive mediastinal staging procedure for patients with potentially operable NSCLC and allows histologic confirmation or exclusion of $\mathrm{N} 2$ or $\mathrm{N} 3$ disease in most patients. ${ }^{2,3}$ Performing re-mediastinoscopy is recognized as technically difficult because of adhesions and fibrotic changes induced by the initial procedure and induction treatment. ${ }^{4,5}$ As a result, it has lower accuracy ${ }^{6,7}$ compared with primary mediastinoscopy. ${ }^{8}$ Other surgical approaches, such as thoracoscopy, are invasive and costly. The accuracies of imaging techniques such as computed tomography (CT) and positron emission tomography (PET)/CT for restaging varies largely. ${ }^{5,9,10}$ The low sensitivity and specificity of imaging techniques for mediastinal restaging necessitate tissue sampling for the accurate determination of mediastinal lymph node status.

Minimally invasive procedures such as of endobronchial ultrasound-guided transbronchial needle aspiration (EBUS-TBNA) and endoscopic ultrasound-guided fine-needle aspiration (EUS-FNA) are used for detecting mediastinal nodal metastases. Both techniques are confirmed with reliably accurate results for the initial staging of lung cancer. ${ }^{1-13}$ There have been an increasing number of reports that analyze the accuracy in the restaging of the mediastinum, whereas the numbers recruited within each study are relatively small and the precision on the derived estimates in each is wide. ${ }^{10,14,15}$ Thus, we aimed to carry out a systematic review and pooled data analysis with valuable data to understand the diagnostic operating characteristics EBUS-TBNA and EUS-FNA for the restaging of mediastinal lymph nodes after induction treatment for lung cancer.

\section{MATERIALS AND METHODS}

The present study was performed as a systematic review, in accordance to the meta-analysis of observational studies in epidemiology guidelines for systematic reviews of observational studies (Table E1). In addition, we also conducted in line with the preferred reporting items for systematic reviews and meta-analysis statement for reporting systematic reviews and meta-analysis (Table E2).

\section{Search Strategy and Selection Criteria}

A systematic literature search was performed on Embase and PubMed databases from conception to March 2019. We used a combination of index terms and free text words related to mediastinal restaging in lung cancer (eg, "lung cancer," "mediastinal restaging") and endosonography (eg, "endobronchial ultrasound," "endoscopic ultrasound," "endosonography," "ultrasound bronchoscope," "fine-needle aspiration"). Our search had no language restrictions. In addition, the reference lists of relevant publications were searched as a supplement.

\section{Study Eligibility}

Two independent investigators examined titles and abstracts of all search results. The included studies met the following criteria: (1) Patients with lung cancer with mediastinal lymph node metastases that were previously pathologically diagnosed; (2) patients who received induction treatment, such as platinum-based chemotherapy, radiotherapy, or both; (3) patients who had stable disease or partial response after induction treatment defined by radiologists; (4) negative results for lymph node metastases by EBUS-TBNA/EUS-FNA were verified by surgical approaches, such as mediastinoscopy or thoracotomy. Reviews, case reports, editorials, and expert opinions were excluded.

\section{Data Extraction}

Data extraction was performed by 1 investigator and verified by a second investigator. Disagreements were resolved by consensus. For each included study, we extracted relevant data about tumor stage at first staging, details of the endoscopic testing protocol, type and duration of induction treatment, complications occurring during the endoscopic procedures, and confirmatory tests for negative results of endoscopic procedures.

We constructed $2 \times 2$ tables for each study, based on the numbers of true- and false-positives and true- and false-negatives for EBUS-TBNA and EUS-FNA. Patients with mediastinal nodal metastases (N2/N3 disease) were deemed positives; patients without mediastinal nodal metastases (N0/N1 disease) were deemed negatives.

We evaluated the diagnostic accuracy of EBUS-TBNA or EUS-FNA alone in detecting mediastinal nodal metastases. Only 1 included study assessed the diagnostic results of the combined use of these 2 approaches. ${ }^{16}$ Furthermore, in a sensitivity analysis, we assess the impact of different modalities of induction treatment (chemotherapy alone and chemoradiotherapy).

\section{Study Quality Assessment}

We used the Quality Assessment of Diagnostic Accuracy Studies-2 tool to assess study quality and the potential for bias. ${ }^{17}$ Two investigators 


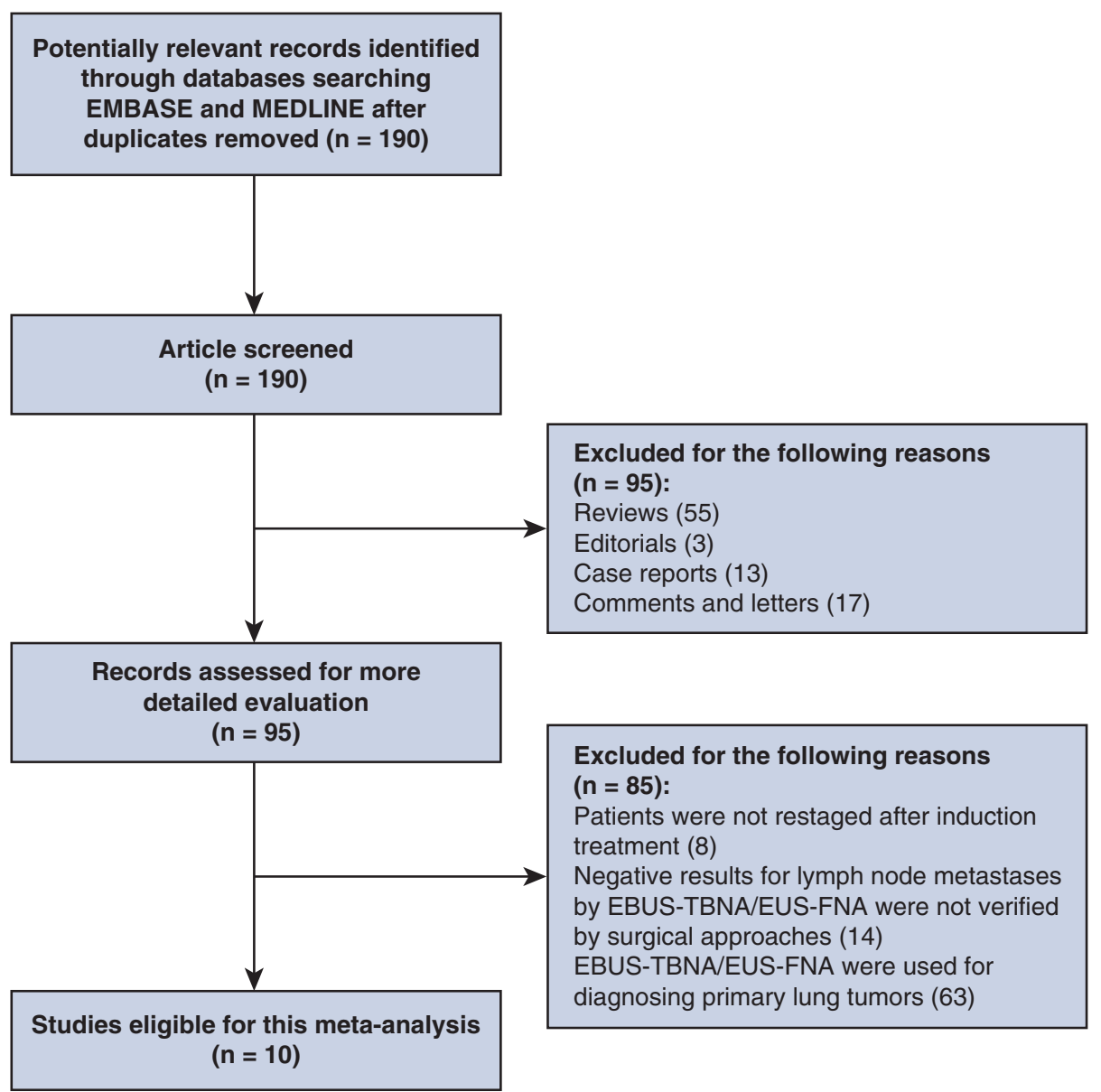

FIGURE 1. Search process of the present meta-analysis. EBUS-TBNA, Endobronchial ultrasound-guided transbronchial needle aspiration; EUS-FNA, endoscopic ultrasound-guided fine-needle aspiration.

(L.J. and W.S.) independently applied the tool to each included study. Disagreements were resolved by consensus.

\section{Statistical Methods}

We performed a bivariate meta-analysis using a linear mixed model approach to calculate summary estimates of sensitivity, specificity, and positive and negative likelihood ratios (LRs) to fit a hierarchical summary receiver-operating characteristic curve. ${ }^{18,19}$ The correlation between sensitivity and specificity makes tests for heterogeneity difficult; most variation in sensitivity is explained by variation in specificity and vice versa. ${ }^{20,21}$ Therefore, statistical tests such as those used in meta-analyses of interventions are not helpful. Because of this, we assumed that heterogeneity was present in our data and planned to address it using a random effects model. We did not assess publication bias, because no proven statistical method exists for this type of meta-analysis. ${ }^{20}$ We used Stata (version 12; StataCorp, College Station, Tex) and Meta-DiSc (Version 1.4; Madrid, Spain) to perform all calculations.

\section{RESULTS}

\section{Characteristics of Eligible Studies}

Ten studies consisting of 558 patients fulfilled the study inclusion criteria and were analyzed. The flowchart of systematic search is presented in Figure 1. The chance- corrected agreement (ie, kappa) between independent reviewers was $0.79 .^{22}$ All included patients were diagnosed pathologically in the initial staging. Five studies included stage IIIA-N2 patients $^{23-27}$ and 5 studies included stage IIIA/B(N2/N3) patients. ${ }^{16,28-31}$ The induction treatments of included studies contained chemotherapy and chemoradiation. The patients who had stable disease or partial response after induction treatment were defined by radiologists through CT or PET/CT. Five studies ${ }^{25-}$ 27,29,31 performed EBUS-TBNA alone, and 4 studies $^{23,24,28,30}$ performed EUS-FNA alone. One study used a combined approach to assess mediastinal lymph node metastases. ${ }^{16}$ All negative results of EBUS-TBNA or EUS-FNA were confirmed by subsequent surgical approaches. No complications were observed. The mean age, gender, pathological diagnose, initial staging, induction treatment, restaging examinations, and confirmatory tests are shown in Table 1. The quality assessment of diagnostic accuracy studies-2 tool for quality assessment of the included studies is shown in Table E3. 
TABLE 1. The characteristics of the included studies

\begin{tabular}{|c|c|c|c|c|c|c|c|c|c|c|c|}
\hline Author (y) & Period & $\begin{array}{c}\text { Total } \\
\text { patients }\end{array}$ & $\begin{array}{l}\text { Mean } \\
\text { age } \\
(\text { range }) \\
\text { or } \pm \text { SD }\end{array}$ & $\begin{array}{c}\text { Female } \\
(\%)\end{array}$ & $\begin{array}{c}\text { Pathologic } \\
\text { diagnosis }(\%)\end{array}$ & $\begin{array}{c}\text { Initial } \\
\text { staging }\end{array}$ & $\begin{array}{l}\text { Induction } \\
\text { treatment }\end{array}$ & $\begin{array}{c}\text { Re- } \\
\text { evaluation } \\
\text { test }\end{array}$ & $\begin{array}{c}\text { Restaging } \\
\text { test }\end{array}$ & $\begin{array}{c}\text { Confirmatory } \\
\text { test }\end{array}$ & $\begin{array}{l}\text { Sensitivity and } \\
\text { specificity of } \\
\text { EBUS/EUS for } \\
\text { restaging after } \\
\text { neoadjuvant }\end{array}$ \\
\hline $\begin{array}{l}\text { Annema } \\
\quad(2003)\end{array}$ & 2001.2-2003.3 & 19 & $58(34-73)$ & $6(31.6)$ & $\begin{array}{l}\text { SCC: } 9(47.4) \\
\text { AdC: } 7(36.8) \\
\text { LCC: } 2(10.5) \\
\text { ASC: } 1(5.3)\end{array}$ & IIIA-N2 & $\begin{array}{l}\text { Three cycles } \\
\text { cisplatin-based } \\
\text { chemotherapy }\end{array}$ & CT & EUS & Thoracotomy & $\begin{array}{l}\text { Sensitivity: } 75 \% \\
\quad \text { Specificity: } 100 \%\end{array}$ \\
\hline $\begin{array}{l}\text { Varadarajulu } \\
\quad(2006)\end{array}$ & $2000.7-2004.6$ & 14 & $62.8(51-78)$ & $5(35.7)$ & $\mathrm{NR}$ & IIIA-N2 & $\begin{array}{l}\text { Two cycles of } \\
\text { carboplatin plus } \\
\text { paclitaxel and } \\
\text { radiotherapy }\end{array}$ & $\mathrm{CT} / \mathrm{PET}$ & EUS & Thoracotomy & $\begin{array}{l}\text { Sensitivity: } 87.5 \% \\
\quad \text { Specificity: } 100 \%\end{array}$ \\
\hline $\begin{array}{l}\text { Herth } \\
\qquad(2008)\end{array}$ & $2003.2-2006.3$ & 124 & $58(19-82)$ & $73(58.9)$ & $\begin{array}{l}\text { SCC: } 24(19) \\
\text { AdC: } 79(64) \\
\text { ASC: } 15(12) \\
\text { LCC: } 6(5)\end{array}$ & IIIA-N2 & $\begin{array}{c}\text { Two or } 3 \text { cycles of } \\
\text { cisplatin-based } \\
\text { chemotherapy }\end{array}$ & СT & EBUS & Thoracotomy & $\begin{array}{l}\text { Sensitivity: } 76 \% \\
\quad \text { Specificity: } 100 \%\end{array}$ \\
\hline $\begin{array}{l}\text { Stigt } \\
\qquad(2009)\end{array}$ & 2006.2-2008.5 & 28 & $60(47-78)$ & $6(21.4)$ & $\begin{array}{l}\text { AdC: } 6(21.4) \\
\text { SCC: } 15 \text { (53.6) } \\
\text { NS-NSCLC: } 7 \text { (25) }\end{array}$ & IIIA-N2 & $\begin{array}{r}\text { chemoradiation: } 22 \\
\text { chemotherapy: } 6\end{array}$ & PET-CT & EUS & Thoracotomy & $\begin{array}{l}\text { Sensitivity: } 76 \% \\
\quad \text { Specificity: } 100 \%\end{array}$ \\
\hline $\begin{array}{l}\text { Szlubowski } \\
\text { (2010) }\end{array}$ & 2007.6-2008.12 & 61 & $59.3 \pm 7.5$ & $12(19.7)$ & NR & IIIA-N2 & $\begin{array}{l}\text { Three to } 5 \text { cycles of } \\
\text { cisplatin plus } \\
\text { vinorelbine }\end{array}$ & СТ & EBUS & TEMLA & $\begin{array}{l}\text { Sensitivity: } 67 \%, \\
\quad \text { Specificity: } 86 \%\end{array}$ \\
\hline $\begin{array}{l}\text { Bartheld } \\
\text { (2011) }\end{array}$ & 2003.3-2009.3 & 58 & $\mathrm{NR}$ & $25(43.1)$ & $\begin{array}{l}\text { AdC: } 26(45) \\
\text { SCC: } 21(36) \\
\text { NS: } 8 \text { (14) } \\
\text { ASC: } 1 \text { (2) } \\
\text { ACC: } 1 \text { (2) } \\
\text { NC: } 1 \text { (2) }\end{array}$ & IIIA/B-N2/3 & $\begin{array}{l}\text { Two or } 3 \text { cycles of } \\
\text { platinum-based } \\
\text { chemotherapy: } 55 \text {; } \\
\text { chemoradiation: } 3\end{array}$ & СТ & EUS & $\begin{array}{l}\text { Thoracotomy/ } \\
\text { mediastinoscopy }\end{array}$ & $\begin{array}{l}\text { Sensitivity: } 44 \% \\
\quad \text { Specificity: } 100 \%\end{array}$ \\
\hline $\begin{array}{l}\text { Zielinski } \\
\quad(2013)\end{array}$ & 2007.1-2010.12 & 88 & NR & NR & NR & IIIA/B-N2/3 & Chemoradiation & CT & EBUS & TEMLA & $\begin{array}{l}\text { Sensitivity: } 64.3 \% \\
\quad \text { Specificity: } 100 \%\end{array}$ \\
\hline $\begin{array}{c}\text { Szlubowski } \\
\text { (2014) }\end{array}$ & 2009.1-2012.12 & 106 & $61.5 \pm 8.1$ & $28(26.4)$ & NR & IIIA/B-N2/3 & $\begin{array}{l}\text { Three to } 5 \text { cycles of } \\
\quad \text { cisplatin plus } \\
\text { vinorelbine }\end{array}$ & NR & EBUS/EUS & TEMLA & $\begin{array}{c}\text { Combine: } 67.3 \%, 96 \% \\
\text { EBUS: } 48 \%, 98 \% \text {; } \\
\text { EUS: } 61 \%, 98 \%\end{array}$ \\
\hline $\begin{array}{l}\text { Erdogan } \\
\quad(2017)\end{array}$ & 2011.1-2013.12 & 44 & $58.3 \pm 8.6$ & $5(11.4)$ & $\begin{array}{l}\text { NS: } 11(25) \\
\text { SCC: } 22(50) \\
\text { AdC: } 10(22.7) \\
\text { Mix NSCLC and } \\
\text { SCLC: } 1(2.3)\end{array}$ & IIIA-N2 & $\begin{array}{l}\text { Three cycles of } \\
\text { platinum-based } \\
\text { chemotherapy, } \\
\text { or radiotherapy, } \\
\text { or both }\end{array}$ & CT/PET & EBUS & $\begin{array}{l}\text { Thoracotomy/ } \\
\text { mediastinoscopy }\end{array}$ & $\begin{array}{l}\text { Sensitivity: } 82.1 \% \\
\quad \text { Specificity: } 100 \%\end{array}$ \\
\hline $\begin{array}{l}\text { Yoon } \\
\text { (2018) }\end{array}$ & 2012.10-2015.7 & 16 & $58(39-73)$ & $6(37.5)$ & NSCLC & IIIA-N2 & Chemoradiation & CT/PET & EBUS & surgery & $\begin{array}{r}\text { Sensitivity: } 33.3 \% \\
\text { specificity: } 75 \%\end{array}$ \\
\hline
\end{tabular}

$S D$, Standard deviation; $E B U S$, endobronchial ultrasound; $E U S$, endoscopic ultrasound; $S C C$, squamous carcinoma; $A d C$, adenocarcinoma; $C T$, computed tomography; $N R$, not reported; PET, positron emission tomography; $N C$, neuroendocrine carcinoma; $N S C L C$, non-small cell lung cancer; $N S$ - $N S C L C$, not specified; TEMLA, transcervical extended mediastinal lymphadenectomy; SCLC, small cell lung cancer.

\section{Diagnostic Accuracy of Endobronchial Ultrasound- Guided Transbronchial Needle Aspiration}

The pooled sensitivity of EBUS-TBNA was $65 \%(95 \%$ confidence interval $[\mathrm{CI}], 52-76)$, and specificity was $99 \%$ (95\% CI, 78-100) (Figure 2, A). The area under the hierarchical summary receiver-operating characteristic curve was 0.85 (95\% CI, 0.81-0.88) (Figure 2, B). The LR- was 0.35 (95\% CI, 0.25-0.50) (Table 2).

\section{Diagnostic Accuracy of Endoscopic Ultrasound- Guided Fine-Needle Aspiration}

The pooled sensitivity of EUS-FNA was $73 \%$ (95\% CI, 52-87), and specificity was $99 \%(95 \% \mathrm{CI}, 90-100)$ (Figure 3, A). The area under the curve was $0.99(95 \%$ CI, 0.98-1) (Figure 3, B), and LR- was 0.27 (95\% CI, 0.14-0.53) (Table 2).

\section{Subgroup Analysis}

Moreover, we evaluated the impact of different modalities of induction treatment (chemotherapy alone and chemoradiotherapy). For patients who received chemotherapy alone, the pooled sensitivity of endosonography with lymph node sampling for the restaging was $66 \%(95 \% \mathrm{CI}, 56-75)$, and specificity was $100 \% \quad(95 \%$ CI, 34-100) (Figure 4, A). For patients who received chemoradiotherapy, the results seemed similar with sensitivity of $77 \% \quad(95 \% \mathrm{CI}$, $47 \%-92 \%)$ and specificity of $99 \% \quad(95 \%$ CI, $48-$ 100) (Figure 4, B) (Table 2).

\section{DISCUSSION}

Accurate mediastinal restaging of lung cancer is crucial because the stage of disease directly determines the 

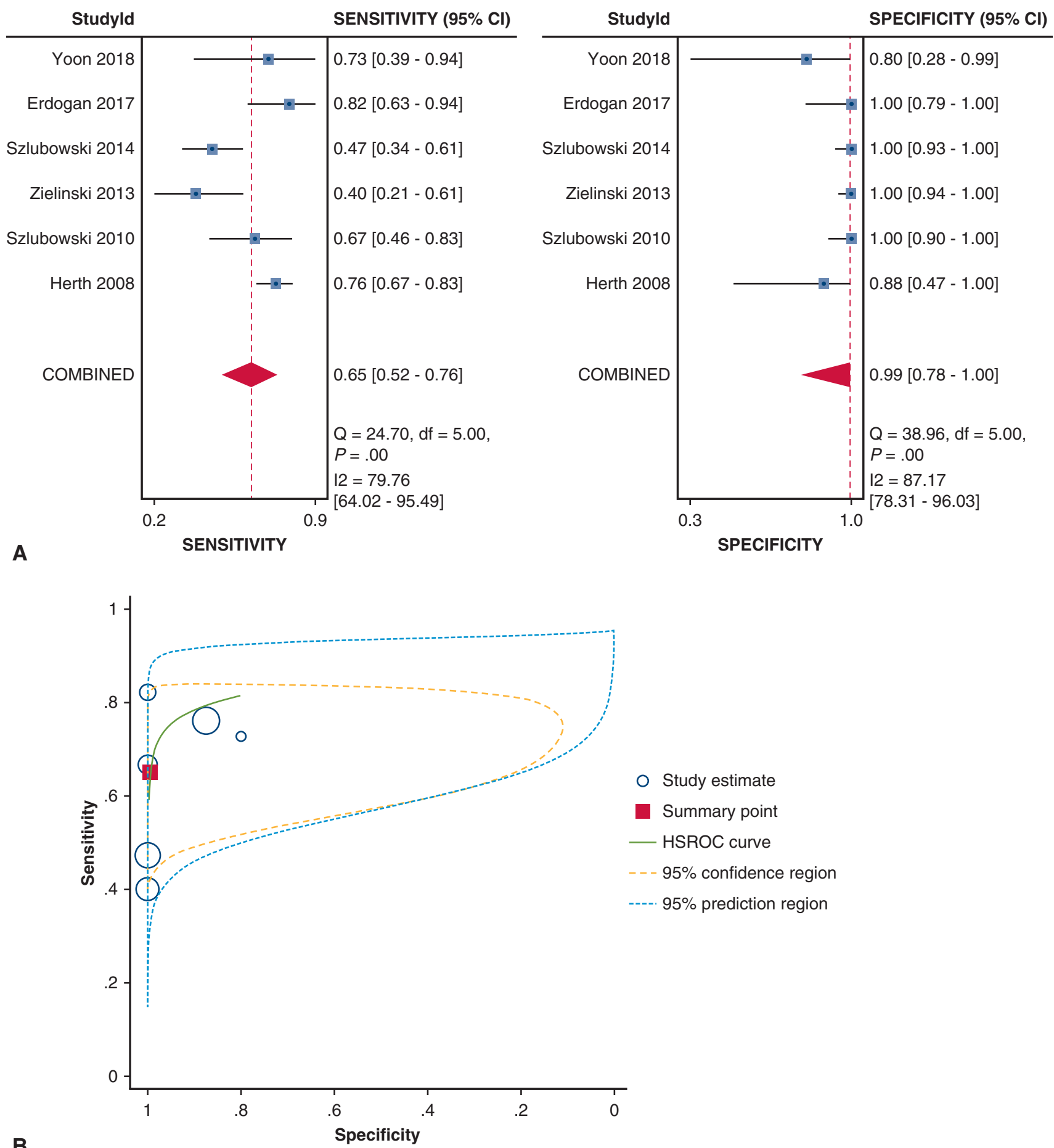

B

FIGURE 2. The sensitivity, specificity, and hierarchical summary receiver operating characteristic of EBUS-TBNA. A, The pooled sensitivity of EBUS-TBNA was $65 \%$ (95\% CI, 52-76), and specificity was $99 \%$ (95\% CI, 78-100). B, The area under the hierarchical summary receiver operating characteristic curve was 0.85 (95\% CI, 0.81-0.88). CI, Confidence interval; HSROC, hierarchical summary receiver-operating characteristic.

prognosis and guides treatment options. Endosonography with lymph node sampling has been confirmed with more favorable results than all other commonly used techniques for mediastinal staging of lung cancer. Although widely accepted in NSCLC staging, little is known about the role of EBUS-TBNA and EUS-FNA in lung cancer restaging after induction treatment. To our knowledge, this is the first state-of-the-art pooled data analysis on the diagnostic 
TABLE 2. The diagnostic accuracy of the included studies

\begin{tabular}{|c|c|c|c|c|c|}
\hline Variables & No. of patients & $\begin{array}{l}\text { Pooled sensitivity } \\
(95 \% \text { CI })\end{array}$ & $\begin{array}{l}\text { Pooled specificity } \\
(95 \% \text { CI })\end{array}$ & $\begin{array}{l}\text { Negative likelihood } \\
\text { ratio }\end{array}$ & AUC \\
\hline \multicolumn{6}{|l|}{ In all mediastinal stations } \\
\hline Overall & 558 & $0.70(0.60-0.79)$ & $1.00(0.87-1.00)$ & $0.30(0.22-0.41)$ & $0.91(0.88-0.93)$ \\
\hline EBUS-TBNA & 440 & $0.65(0.52-0.76)$ & $0.99(0.78-1.00)$ & $0.35(0.25-0.50)$ & $0.85(0.81-0.88)$ \\
\hline EUS-FNA & 226 & $0.73(0.52-0.87)$ & $0.99(0.90-1.00)$ & $0.27(0.14-0.53)$ & $0.99(0.90-1.00)$ \\
\hline Combine & 106 & $0.67(0.53-0.79)$ & $0.96(0.86-0.99)$ & N/A & $0.81(0.73-0.87)$ \\
\hline \multicolumn{6}{|l|}{ Subgroup analysis } \\
\hline Chemotherapy alone & 365 & $0.66(0.56-0.75)$ & $1.00(0.34-1.00)$ & $0.35(0.26-0.48)$ & $0.80(0.77-0.84)$ \\
\hline Chemotherapy radiotherapy & 146 & $0.77(0.47-0.92)$ & $0.99(0.48-1.00)$ & $0.24(0.09-0.64)$ & $0.96(0.94-0.98)$ \\
\hline
\end{tabular}

If negative likelihood ratio (LR-) is smaller: essentially a definite diagnosis when negative result. $95 \%$ CI, 95\% Confidence interval; $A U C$, area under the curve; $E B U S-T B N A$, endobronchial ultrasound-guided transbronchial needle aspiration; EUS-FNA, endoscopic ultrasound-guided fine-needle aspiration; N/A, not applicable.

operating characteristics of endosonography with lymph node sampling for lung cancer restaging. In the present study, we found that EBUS-TBNA and EUS-FNA were accurate methods for restaging mediastinal lymph nodes after induction treatment for lung cancer using chemotherapy or chemoradiation therapy.

The staging of lymph nodes in patients with lung cancer is typically performed using an invasive or noninvasive approach. Chest CT and PET scans are the most used noninvasive methods and are reported to be safe but have limited sensitivity and specificity. CT has low accuracy in the restaging of the mediastinum with a diagnostic accuracy of 0.58 to $0.60 .^{5,6}$ In the previous reports, PET/CT had high sensitivity rates of $73 \%$ to $92 \%$. However, because of false-positive results, its specificity ranged between $62 \%$ and $89 \% .{ }^{5,10}$ Deppen and colleagues ${ }^{32}$ performed a metaanalysis and reported that the use of PET/CT was less specific in diagnosing malignancy in populations with endemic infectious lung diseases compared with nonendemic regions. The pooled specificity was only $61 \%$ in areas with endemic infectious lung diseases. According to these results, reliance on imaging techniques alone is not sufficient to confirm metastasis; thus, histopathologic diagnosis should be considered.

Mediastinoscopy has been the gold standard in staging mediastinal lymph nodes. The average sensitivity of mediastinoscopy is $80 \%$; however, it has a $2 \%$ risk of major morbidity and $0.08 \%$ risk of mortality, and is substantially costly. ${ }^{33,34}$ Repeat mediastinoscopy, although possible, is technically difficult and has a lower accuracy compared with primary mediastinoscopy. ${ }^{35}$ EBUS-TBNA and EUSFNA are both minimally invasive procedures for detecting mediastinal nodal metastases and have become the standard of care for staging patients with lung cancers. The American College of Chest guidelines recommended EBUSTBNA as the invasive method of choice for the staging of lung cancer. ${ }^{13}$ More recently, the European Society of Gastrointestinal Endoscopy in collaboration with the European Respiratory and Thoracic Surgeons Societies issued new guidelines recommending endosonography over surgery for staging of NSCLC. When EUS-FNA is available, they also recommended the combination of EBUSTBNA and EUS-FNA over either test alone. ${ }^{36}$ These guidelines gave a grade $\mathrm{C}$ recommendation for the use of EBUSTBNA and EUS-FNA for restaging the mediastinum after neoadjuvant therapy (Video 1).

EBUS-TBNA has been shown to have a high yield for diagnosing and staging lung cancer ranging from $89 \%$ to $98 \% \cdot{ }^{37-40}$ Additionally, the sensitivities of EUS-FNA ranged from $45 \%$ to $80 \%$ for initial staging of lung cancer. ${ }^{41-43}$ In the present study, we found that for lung cancer restaging, the pooled sensitivities of EBUS-TBNA and EUS-FNA were $65 \%$ and $73 \%$, respectively, which were lower compared with reported sensitivity for the initial staging of lung cancer.

The main limitations of EBUS-TBNA or EUS-FNA were that some lymph node stations such as level 5 and 6 are not accessible using either strategy. However, combined EBUSTBNA and EUS-FNA could achieve near-complete minimally invasive mediastinal staging. ${ }^{44,45}$ Multiple studies demonstrated a higher diagnostic yield for EBUS-TBNA compared with cervical mediastinoscopy. ${ }^{46,47}$ Zhang and colleagues $^{48}$ conducted a meta-analysis with the aim to assess the diagnostic yield of the combined EBUS-TBNA and EUS-FNA approaches in NSCLC staging. The sensitivity and specificity were $86 \%$ and $100 \%$, respectively, and the NLR was 0.15 . The sensitivity of the combined approach was significantly better than that of either strategy alone. ${ }^{48}$ Only 1 study used the combined endosonography approach for restaging NSCLC and the reported sensitivity, specificity, and accuracy were $70 \%, 96 \%$, and $83 \%$, respectively.

Our analysis of the pooled data showed that the specificity of EBUS-TBNA and or EUS-FNA is perfect, but the sensitivity is defective. This may be attributed to the fact that induction treatment with chemotherapy or chemoradiation led to the formation of necrosis and fibrosis in the metastatic lymph nodes. Sampling of these lymph nodes may be more difficult with less cellular material for histologic analysis. In these treated metastatic lymph nodes, the malignant cells may be focal within the node or located within areas of 

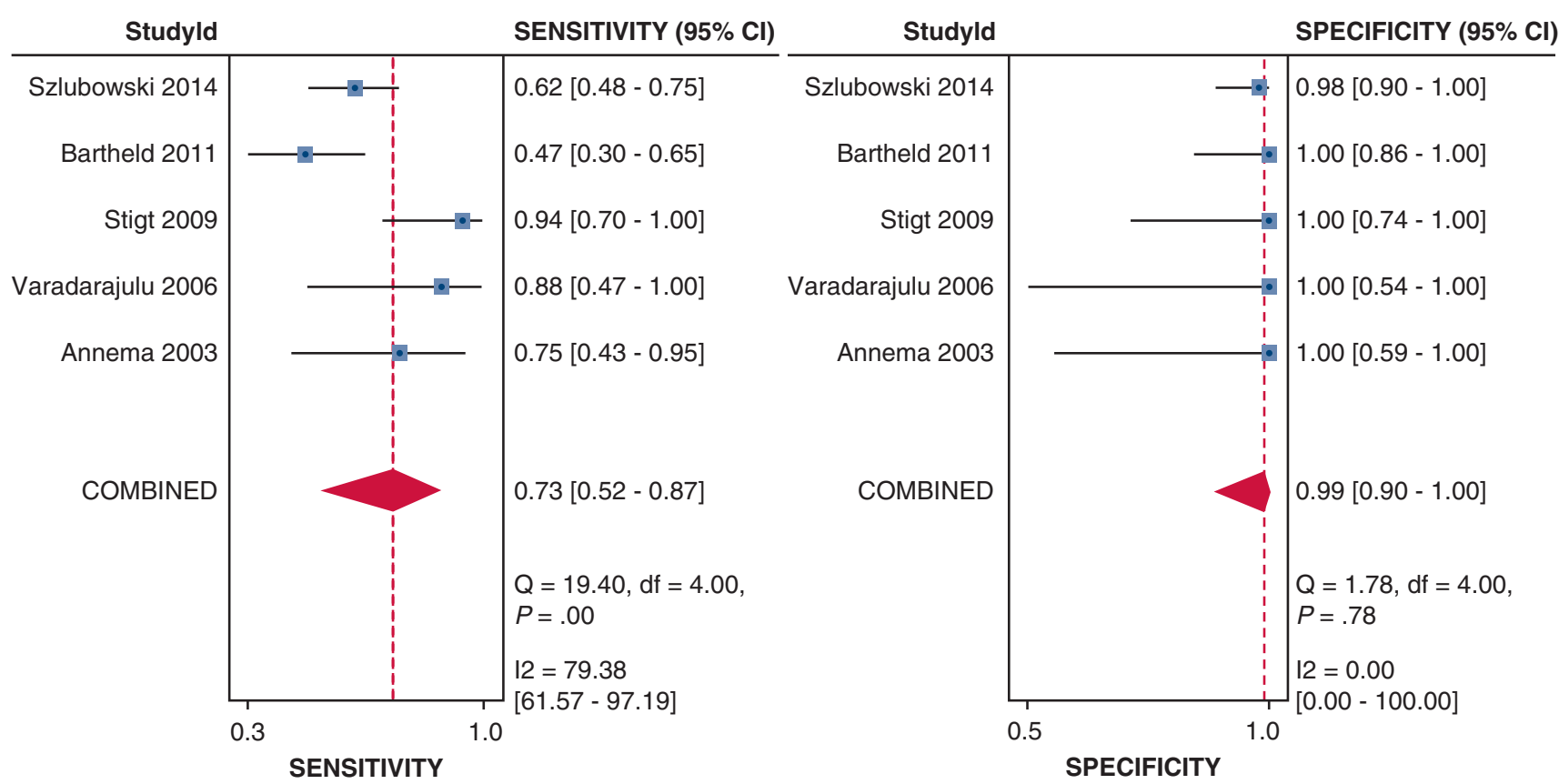

A

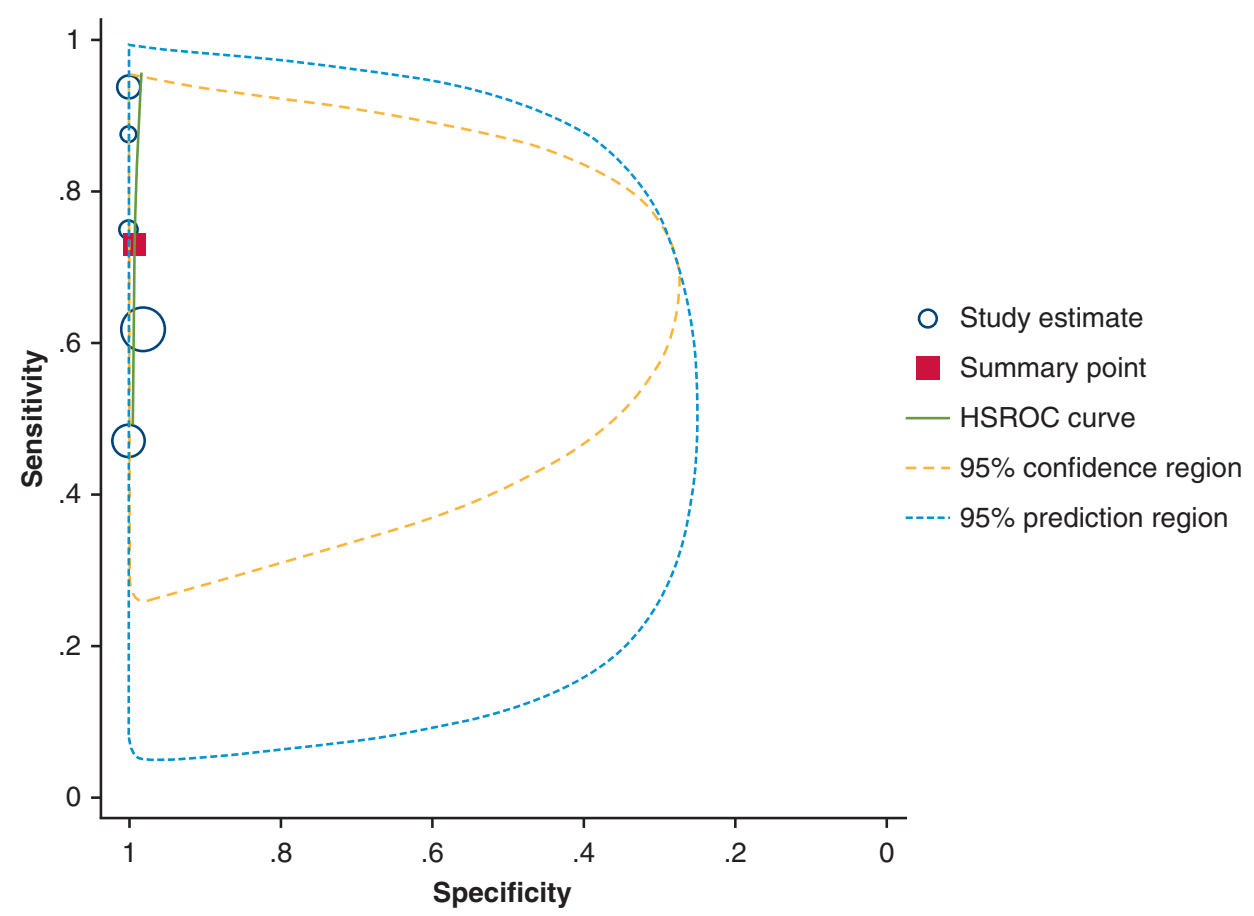

B

FIGURE 3. The sensitivity, specificity, and hierarchical summary receiver-operating characteristic of EUS-FNA. A, The pooled sensitivity of EUS-FNA was $73 \%$ (95\% CI, 52-87), and specificity was $99 \%$ (95\% CI, 90-100). B, The area under the curve was 0.99 (95\% CI, 0.98-1). CI, Confidence interval; HSROC, hierarchical summary receiver-operating characteristic.

dense extracellular matrix. This may partially explain why, in many of the false-negative results, lymph node tissue was aspirated successfully but no malignant cells were seen. Likewise, pathologic interpretation is often more difficult when necrosis is present within the aspirated sample.
In centers where EBUS-TBNA is not available, EUSFNA and mediastinoscopy are acceptable alternatives for the diagnosis and staging of lung cancer. The American College of Physicians Executive Summary recommended the use EBUS-TBNA or EUS-FNA or combined EBUS/ 

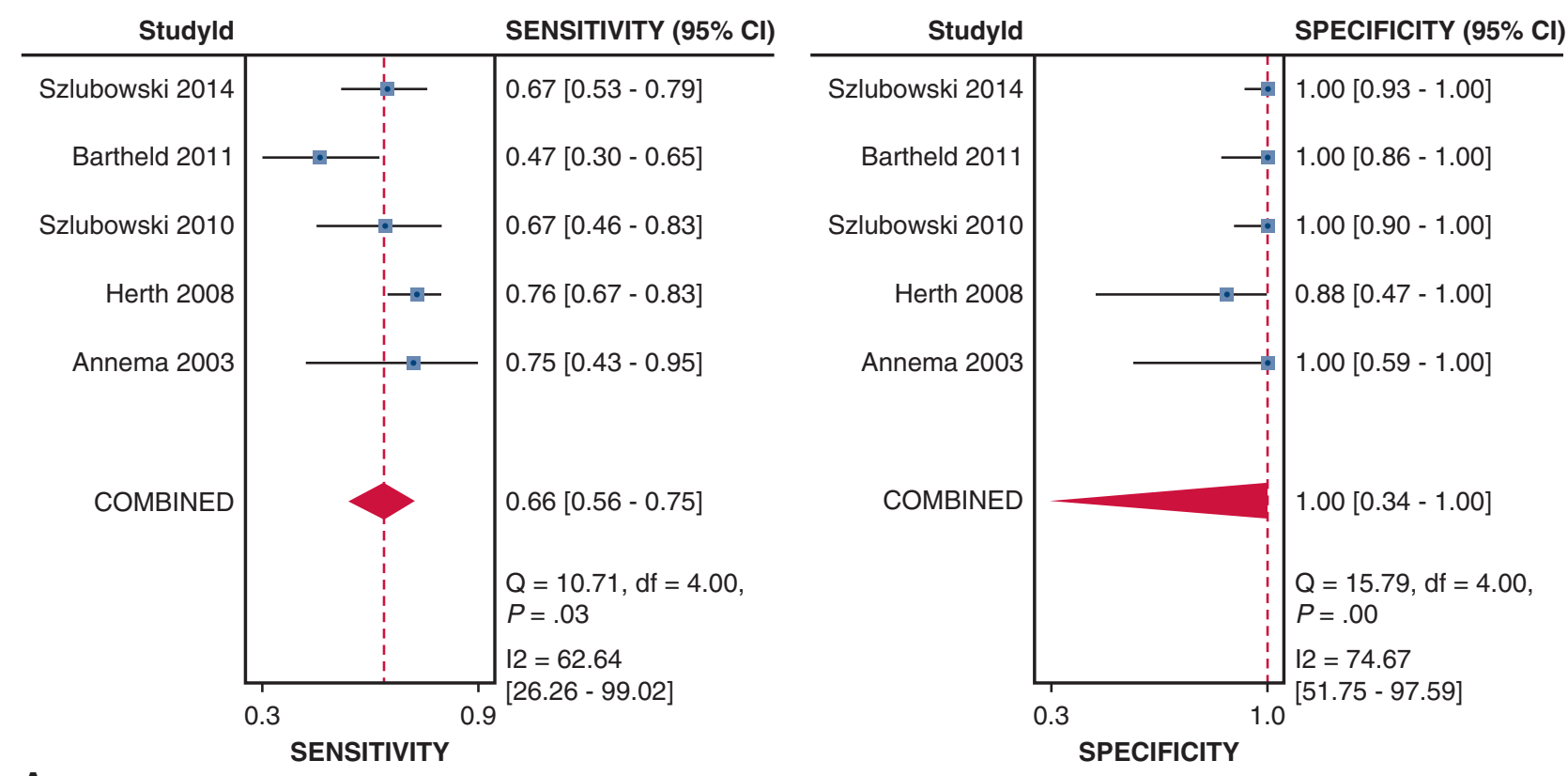

A
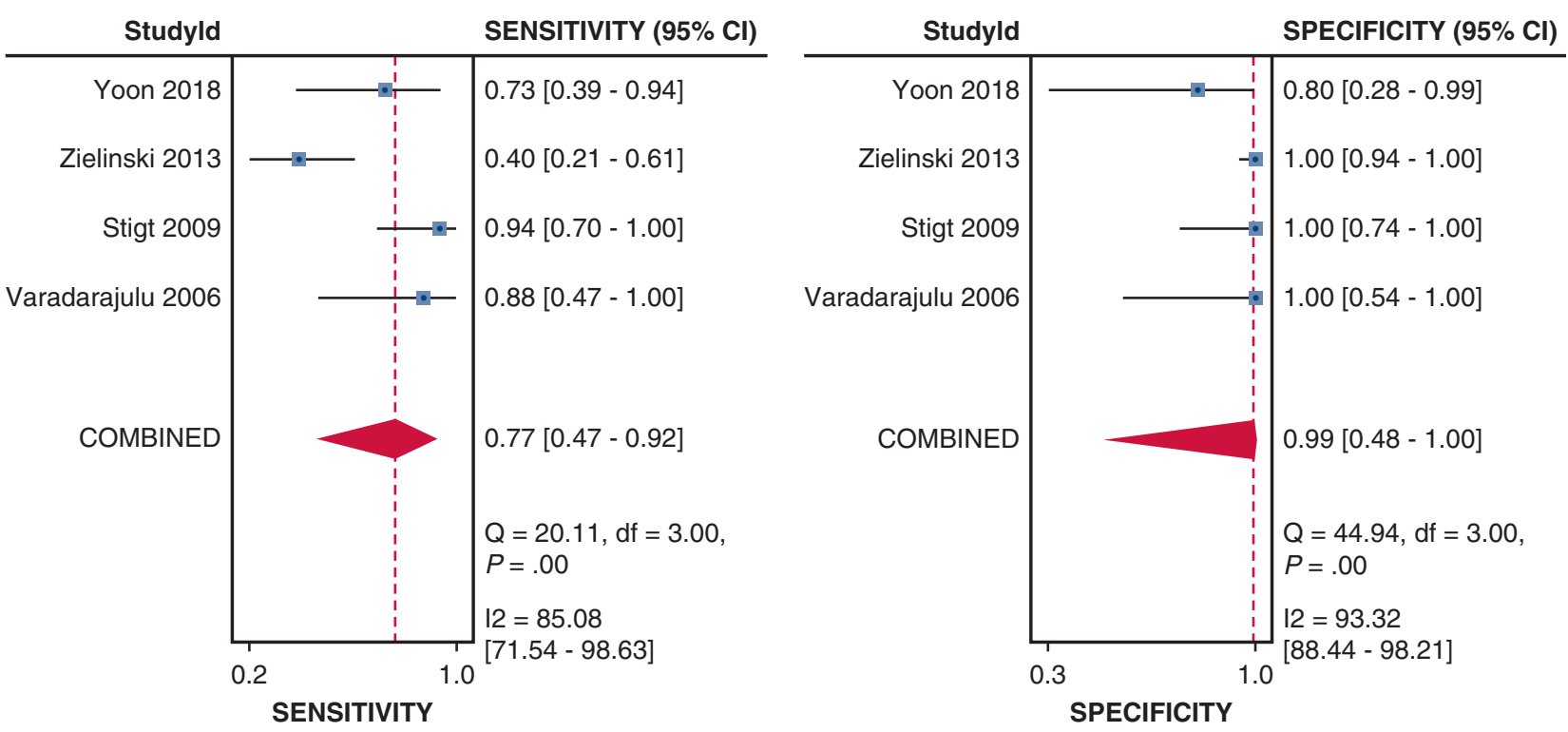

.

FIGURE 4. The sensitivity, specificity, and hierarchical summary receiver-operating characteristic of endosonography for patients who received chemotherapy alone and chemoradiotherapy. A, For patients who received chemotherapy alone, the pooled sensitivity of endosonography with lymph node sampling for the restaging was $66 \%$ (95\% CI, 56-75) and specificity was $100 \%$ (95\% CI, 34-100). B, For patients who received chemoradiotherapy, the results seemed similar with sensitivity of $77 \%(95 \% \mathrm{CI}, 47-92)$ and specificity of $99 \%$ (95\% CI, 48-100). CI, Confidence interval.

EUS-FNA for lung cancer staging over surgical staging. They based the recommendation on the availability of the technology and the appropriate skills of the proceduralist. ${ }^{13}$ The combined EBUS-TBNA and EUS-FNA is the preferred procedure over either one alone. This was also recommended in the guidelines by the European Society of Gastrointestinal Endoscopy Guideline, in cooperation with the European Respiratory Society and the European Society of Thoracic Surgeons. ${ }^{49}$ The EUS-FNA may be performed in the same setting with EBUS-TBNA and using the same EBUS bronchoscope and by the pulmonologists. It is usually referred to as endoscopic ultrasound-bronchoscope fine-needle aspiration: (EUS-B-FNA). This technique does not significantly increase the cost of the procedure. The EBUS scope is usually retracted from the airways and positioned into the esophagus to perform the EUS- 


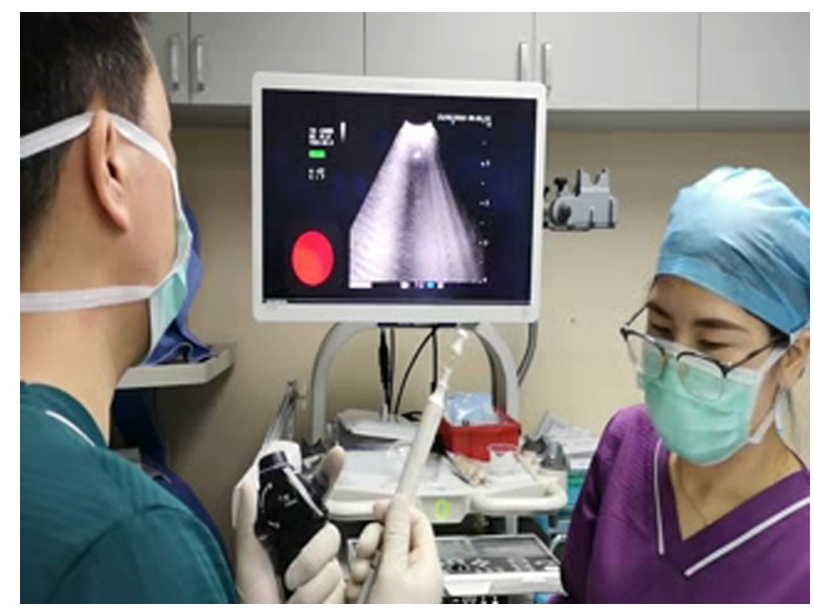

VIDEO 1. The process of EBUS operation. Video available at: https:// www.jtcvs.org/article/S0022-5223(19)31649-6/fulltext.

FNA. More recently, the EBUS scope was used to perform EUS-B-FNA of the left adrenal nodules in patients with lung cancer as part of staging. The EBUS scope is advanced to the stomach, and the left adrenal nodule is then identified and sampled under real-time EUS-B-FNA. In a recent article by Crombag and colleagues, ${ }^{50}$ the mediastinal and left adrenal gland were appropriately sampled using the same EBUS scope. This was suggested to lower the cost in selected patients. However, no cost-effective data are available about this topic, and more studies are warranted.

\section{Study Limitations}

Some limitations need to be acknowledged. There was a lack of standardization of diagnostic testing, and PET/CT was not used routinely. Also, the strategies used for primary pathologic staging and induction treatment varied. Different chemotherapy agents and various numbers of treatment cycles were used, and some patients received radiation in addition of chemotherapy. This has the potential of influencing the outcome of restaging lung cancer. As the lung cancer management continues to advance, more neoadjuvant agents such as nivolumab to block the programmed death 1 protein or agents that target its ligand will be more widely used, and this will surely affect the outcome of lung cancer restaging. ${ }^{51}$ More studies are needed to further investigate the ideal restaging procedures. In the included studies, there were no description of the lymph node histopathologic structure. Such description may help the endoscopists when sampling lymph nodes for restaging lung cancers. The distribution of malignant cells in the treated lymph nodes could be a crucial information and warrants further investigation. Having the malignant cells distributed centrally versus peripherally or scattered focally inside the lymph node may guide the endoscopists in choosing the location the needle insertion during EBUSTBNA or EUS-FNA. This may have an impact on choosing the size of the sampling needle used and how many locations inside the lymph node should the endoscopists sample and the number of passed needed to increase the yield. Moreover, the sensitivity and specificity of EBUS or EUS apply to only the locations that are possible to assess with either modality. For example, EUS may have limited access to certain mediastinal nodes (4R), and EBUS has limitations to lower mediastinal nodes (stations 8 and 9). There is no comparability between the 2 approaches because they are stand-alone staging techniques. Prospective studies are warranted to clarify all these questions and help to increase the yield of endosonography for lymph node sampling for restaging lung cancers.

\section{CONCLUSIONS}

Endosonography with lymph node sampling is an accurate and safe technique in mediastinal restaging in lung cancer patients after induction treatment.

\section{Conflict of Interest Statement}

Authors have nothing to disclose with regard to commercial support.

\section{References}

1. Ettinger DS, Wood DE, Aisner DL, Akerley W, Bauman J, Chirieac LR, et al. Non-small cell lung cancer, Version 5.2017, NCCN clinical practice guidelines in oncology. J Natl Compr Cancer Netw. 2017;15:504-35.

2. Hammoud ZT, Anderson RC, Meyers BF, Guthrie TJ, Roper CL, Cooper JD, et al. The current role of mediastinoscopy in the evaluation of thoracic disease. J Thorac Cardiovasc Surg. 1999;118:894-9.

3. Porte H, Roumilhac D, Eraldi L, Cordonnier C, Puech P, Wurtz A. The role of mediastinoscopy in the diagnosis of mediastinal lymphadenopathy. Eur J Cardiothorac Surg. 1998;13:196-9.

4. Pitz CC, Maas KW, Van Swieten HA, de la Riviere AB, Hofman P, Schramel FM. Surgery as part of combined modality treatment in stage IIIB non-small cell lung cancer. Ann Thorac Surg. 2002;74:164-9.

5. De Leyn P, Stroobants S, De Wever W, Lerut T, Coosemans W, Decker G, et al Prospective comparative study of integrated positron emission tomographycomputed tomography scan compared with remediastinoscopy in the assessment of residual mediastinal lymph node disease after induction chemotherapy for mediastinoscopy-proven stage IIIA-N2 Non-small-cell lung cancer: a Leuven Lung Cancer Group Study. J Clin Oncol. 2006;24:3333-9.

6. Mateu-Navarro M, Rami-Porta R, Bastus-Piulats R, Cirera-Nogueras L, Gonzalez-Pont G. Remediastinoscopy after induction chemotherapy in non-small cell lung cancer. Ann Thorac Surg. 2000;70:391-5.

7. Van Schil P, van der Schoot J, Poniewierski J, Pauwels M, Carp L, Germonpre P, et al. Remediastinoscopy after neoadjuvant therapy for non-small cell lung cancer. Lung Cancer. 2002;37:281-5.

8. Toloza EM, Harpole L, Detterbeck F, McCrory DC. Invasive staging of non-small cell lung cancer: a review of the current evidence. Chest. 2003;123(1 Suppl): 157S-66S

9. Pottgen C, Levegrun S, Theegarten D, Marnitz S, Grehl S, Pink R, et al. Value of 18F-fluoro-2-deoxy-D-glucose-positron emission tomography/computed tomography in non-small-cell lung cancer for prediction of pathologic response and times to relapse after neoadjuvant chemoradiotherapy. Clin Cancer Res. 2006; 12:97-106.

10. Cerfolio RJ, Bryant AS, Ojha B. Restaging patients with N2 (stage IIIa) nonsmall cell lung cancer after neoadjuvant chemoradiotherapy: a prospective study. J Thorac Cardiovasc Surg. 2006;131:1229-35.

11. Micames CG, McCrory DC, Pavey DA, Jowell PS, Gress FG. Endoscopic ultrasound-guided fine-needle aspiration for non-small cell lung cancer staging: a systematic review and metaanalysis. Chest. 2007;131:539-48.

12. Adams K, Shah PL, Edmonds L, Lim E. Test performance of endobronchial ultrasound and transbronchial needle aspiration biopsy for mediastinal staging in 
patients with lung cancer: systematic review and meta-analysis. Thorax. 2009;64: 757-62.

13. Detterbeck FC, Lewis SZ, Diekemper R, Addrizzo-Harris D, Alberts WM. Executive Summary: Diagnosis and management of lung cancer, 3rd ed: American College of Chest Physicians evidence-based clinical practice guidelines. Chest. 2013;143(5 Suppl):7S-37S.

14. De Leyn P, Dooms C, Kuzdzal J, Lardinois D, Passlick B, Rami-Porta R, et al. Revised ESTS guidelines for preoperative mediastinal lymph node staging for non-small-cell lung cancer. Eur J Cardiothorac Surg. 2014;45:787-98.

15. Nasir BS, Bryant AS, Minnich DJ, Wei B, Dransfield MT, Cerfolio RJ. The efficacy of restaging endobronchial ultrasound in patients with non-small cell lung cancer after preoperative therapy. Ann Thorac Surg. 2014;98:1008-12.

16. Szlubowski A, Zielinski M, Soja J, Filarecka A, Orzechowski S, Pankowski J, et al. Accurate and safe mediastinal restaging by combined endobronchial and endoscopic ultrasound-guided needle aspiration performed by single ultrasound bronchoscope. Eur J Cardiothorac Surg. 2014;46:262-6.

17. Whiting PF, Rutjes AW, Westwood ME, Mallett S, Deeks JJ, Reitsma JB, et al. QUADAS-2: a revised tool for the quality assessment of diagnostic accuracy studies. Ann Intern Med. 2011;155:529-36.

18. Chu H, Cole SR. Bivariate meta-analysis of sensitivity and specificity with sparse data: a generalized linear mixed model approach. J Clin Epidemiol. 2006;59: 1331-2. author reply 2-3.

19. Wang F, Gatsonis CA. Hierarchical models for ROC curve summary measures: design and analysis of multi-reader, multi-modality studies of medical tests. Stat Med. 2008;27:243-56.

20. Deeks JJ, Macaskill P, Irwig L. The performance of tests of publication bias and other sample size effects in systematic reviews of diagnostic test accuracy was assessed. J Clin Epidemiol. 2005;58:882-93.

21. Macaskill P, Gatsonis C, Deeks JJ. Analysing and presenting results. In: Deeks JJ, Bossuyt PM, Gatsonis C, eds. Cochrane Handbook for Systematic Reviews of Diagnostic Test Accuracy, Version 1.0. Oxford, UK: The Cochrane Collaboration; 2010.

22. Warrens MJ. Chance-corrected measures for $2 \times 2$ tables that coincide with weighted kappa. Br J Math Stat Psychol. 2011;64(Pt 2):355-65.

23. Annema JT, Veselic M, Versteegh MI, Willems LN, Rabe KF. Mediastinal restaging: EUS-FNA offers a new perspective. Lung Cancer. 2003;42:311-8.

24. Varadarajulu S, Eloubeidi M. Can endoscopic ultrasonography-guided fine-needle aspiration predict response to chemoradiation in non-small cell lung cancer? A pilot study. Respiration. 2006;73:213-20.

25. Herth FJ, Annema JT, Eberhardt R, Yasufuku K, Ernst A, Krasnik M, et al. Endobronchial ultrasound with transbronchial needle aspiration for restaging the mediastinum in lung cancer. J Clin Oncol. 2008;26:3346-50.

26. Cetinkaya E, Usluer O, Yilmaz A, Tutar N, Cam E, Ozgul MA, et al. Is endobronchial ultrasound-guided transbronchial needle aspiration an effective diagnostic procedure in restaging of non-small cell lung cancer patients? Endosc Ultrasound. 2017;6:162-7.

27. Yoon HY, Lee JC, Kim SW, Kim HR, Kim YH, Choi SH, et al. Prognosis of multi-level N2-positive non-small cell lung cancer according to lymph node staging using endobronchial ultrasound-transbronchial biopsy. Thorac Cancer. 2018; 9:684-92.

28. Stigt JA, Oostdijk AH, Timmer PR, Shahin GM, Boers JE, Groen HJ. Comparison of EUS-guided fine needle aspiration and integrated PET-CT in restaging after treatment for locally advanced non-small cell lung cancer. Lung Cancer. 2009;66:198-204.

29. Szlubowski A, Herth FJ, Soja J, Kolodziej M, Figura J, Cmiel A, et al. Endobronchial ultrasound-guided needle aspiration in non-small-cell lung cancer restaging verified by the transcervical bilateral extended mediastinal lymphadenectomy-a prospective study. Eur J Cardiothorac Surg. 2010;37:1180-4.

30. von Bartheld MB, Versteegh MI, Braun J, Willems LN, Rabe KF, Annema JT. Transesophageal ultrasound-guided fine-needle aspiration for the mediastinal restaging of non-small cell lung cancer. J Thorac Oncol. 2011;6:1510-5.

31. Zielinski M, Szlubowski A, Kolodziej M, Orzechowski S, Laczynska E, Pankowski J, et al. Comparison of endobronchial ultrasound and/or endoesophageal ultrasound with transcervical extended mediastinal lymphadenectomy for staging and restaging of non-small-cell lung cancer. J Thorac Oncol. 2013;8: 630-6.

32. Deppen SA, Blume JD, Kensinger CD, Morgan AM, Aldrich MC, Massion PP, et al. Accuracy of FDG-PET to diagnose lung cancer in areas with infectious lung disease: a meta-analysis. JAMA. 2014;312:1227-36.
33. Harewood GC, Wiersema MJ, Edell ES, Liebow M. Cost-minimization analysis of alternative diagnostic approaches in a modeled patient with nonsmall cell lung cancer and subcarinal lymphadenopathy. Mayo Clin Proc. 2002; 77:155-64.

34. Aabakken L, Silvestri GA, Hawes R, Reed CE, Marsi V, Hoffman B. Cost-efficacy of endoscopic ultrasonography with fine-needle aspiration vs. mediastinotomy in patients with lung cancer and suspected mediastinal adenopathy. Endoscopy. 1999;31:707-11.

35. Marra A, Hillejan L, Fechner S, Stamatis G. Remediastinoscopy in restaging of lung cancer after induction therapy. J Thorac Cardiovasc Surg. 2008;135: 843-9.

36. Vilmann P, Clementsen PF, Colella S, Siemsen M, De Leyn P, Dumonceau JM, et al. Combined endobronchial and esophageal endosonography for the diagnosis and staging of lung cancer: European Society of Gastrointestinal Endoscopy (ESGE) guideline, in cooperation with the European Respiratory Society (ERS) and the European Society of Thoracic Surgeons (ESTS). Endoscopy. 2015;47:c1.

37. Yasufuku K, Chiyo M, Koh E, Moriya Y, Iyoda A, Sekine Y, et al. Endobronchial ultrasound guided transbronchial needle aspiration for staging of lung cancer. Lung Cancer. 2005;50:347-54.

38. Yasufuku K, Chiyo M, Sekine Y, Chhajed PN, Shibuya K, Iizasa T, et al. Realtime endobronchial ultrasound-guided transbronchial needle aspiration of mediastinal and hilar lymph nodes. Chest. 2004;126:122-8.

39. Yasufuku K, Nakajima T, Motoori K, Sekine Y, Shibuya K, Hiroshima K, et al. Comparison of endobronchial ultrasound, positron emission tomography, and CT for lymph node staging of lung cancer. Chest. 2006;130:710-8.

40. Herth FJ, Eberhardt R, Becker HD, Ernst A. Endobronchial ultrasound-guided transbronchial lung biopsy in fluoroscopically invisible solitary pulmonary nodules: a prospective trial. Chest. 2006;129:147-50.

41. Vilmann P, Krasnik M, Larsen SS, Jacobsen GK, Clementsen P. Transesophageal endoscopic ultrasound-guided fine-needle aspiration (EUS-FNA) and endobronchial ultrasound-guided transbronchial needle aspiration (EBUSTBNA) biopsy: a combined approach in the evaluation of mediastinal lesions. Endoscopy. 2005;37:833-9.

42. Wallace MB, Pascual JM, Raimondo M, Woodward TA, McComb BL, Crook JE, et al. Minimally invasive endoscopic staging of suspected lung cancer. JAMA. 2008;299:540-6.

43. Szlubowski A, Zielinski M, Soja J, Annema JT, Sosnicki W, Jakubiak M, et al. A combined approach of endobronchial and endoscopic ultrasound-guided needle aspiration in the radiologically normal mediastinum in non-small-cell lung cancer staging-a prospective trial. Eur J Cardiothorac Surg. 2010;37:1175-9.

44. Sheski FD, Mathur PN. Endobronchial ultrasound. Chest. 2008;133:264-70.

45. Vilmann P, Puri R. The complete "medical" mediastinoscopy (EUS-FNA + EBUS-TBNA). Minerva Med. 2007;98:331-8.

46. Annema JT, van Meerbeeck JP, Rintoul RC, Dooms C, Deschepper E, Dekkers OM, et al. Mediastinoscopy vs endosonography for mediastinal nodal staging of lung cancer: a randomized trial. JAMA. 2010;304:2245-52.

47. Ernst A, Anantham D, Eberhardt R, Krasnik M, Herth FJ. Diagnosis of mediastinal adenopathy-real-time endobronchial ultrasound guided needle aspiration versus mediastinoscopy. J Thorac Oncol. 2008;3:577-82.

48. Zhang R, Ying K, Shi L, Zhang L, Zhou L. Combined endobronchial and endoscopic ultrasound-guided fine needle aspiration for mediastinal lymph node staging of lung cancer: a meta-analysis. Eur J Cancer. 2013;49:1860-7.

49. Vilmann P, Clementsen PF, Colella S, Siemsen M, De Leyn P, Dumonceau JM, et al. Combined endobronchial and esophageal endosonography for the diagnosis and staging of lung cancer: European Society of Gastrointestinal Endoscopy (ESGE) guideline, in cooperation with the European Respiratory Society (ERS) and the European Society of Thoracic Surgeons (ESTS). Endoscopy. 2015; 47:545-59.

50. Crombag L, Szlubowski A, Stigt JA, Schuurbiers O, Korevaar DA, Bonta PI, et al. EUS-B-FNA vs conventional EUS-FNA for left adrenal gland analysis in lung cancer patients. Lung Cancer. 2017;108:38-44.

51. Forde PM, Chaft JE, Smith KN, Anagnostou V, Cottrell TR, Hellmann MD, et al. Neoadjuvant PD-1 blockade in resectable lung cancer. N Engl J Med. 2018;378: 1976-86.

Key Words: EBUS, EUS, fine-needle aspiration, lung cancer, mediastinal restaging 
TABLE E1. Meta-analysis of observational studies in epidemiology checklist.

Criteria

Brief description of how the criteria were handled in the meta-analysis

Reporting of background should include

$\sqrt{ }$ Problem definition

$\sqrt{ }$ Hypothesis statement

$\sqrt{ }$ Description of study outcomes

$\sqrt{ }$ Type of exposure or intervention used

$\sqrt{ }$ Type of study designs used

$\sqrt{ }$ Study population

Reporting of search strategy should include

$\sqrt{ }$ Qualifications of searchers

$\sqrt{ }$ Search strategy, including time period included in the synthesis and keywords

$\sqrt{ }$ Databases and registries searched

$\sqrt{ }$ Search software used, name and version, including special features

$\sqrt{ }$ Use of hand searching

$\sqrt{ }$ List of citations located and those excluded, including justifications $\sqrt{ }$ Method of addressing articles published in languages other than English

$\sqrt{ }$ Method of handling abstracts and unpublished studies

$\sqrt{ }$ Description of any contact with authors

Reporting of methods should include

$\sqrt{ }$ Description of relevance or appropriateness of studies assembled

for assessing the hypothesis to be tested

$\sqrt{ }$ Rationale for the selection and coding of data

$\sqrt{ }$ Assessment of confounding

$\sqrt{ }$ Assessment of study quality, including blinding of quality assessors; stratification or regression on possible predictors of study results

$\sqrt{ }$ Assessment of heterogeneity

$\sqrt{ }$ Description of statistical methods in sufficient detail to be replicated

$\sqrt{ }$ Provision of appropriate tables and graphics

Reporting of results should include

$\sqrt{ }$ Graph summarizing individual study estimates and overall estimate

$\sqrt{ }$ Table giving descriptive information for each study included

$\sqrt{ }$ Results of sensitivity testing

$\sqrt{ }$ Indication of statistical uncertainty of findings
Mediastinal restaging after induction treatment is still a difficult and controversial issue.

The diagnostic accuracy of EBUS-TBNA and EUS-FNA for restaging the mediastinum after induction treatment in patients with lung cancer is reliable.

Diagnostic accuracy of EBUS-TBNA and EUS-FNA

Endosonography with lymph node sampling for restaging the mediastinum

We included observation studies.

We placed no restriction.

The credentials of the 2 investigators, Jun Liu and Wenhua Liang, are indicated in the author list.

PubMed from conception to July 2017 EMBASE from conception to July 2017

See "Material and Methods" section in the article

PubMed and EMBASE

We did not use a search software. EndNote was used to merge retrieved citations and eliminate duplications

We hand-searched bibliographies of retrieved papers for additional references

Details of the literature search process are outlined in the flow chart.

We placed no restrictions on language; all included studies have English abstract.

We had contacted a few authors by sending emails for unpublished studies.

We contacted authors who did not reported the types of introduction therapy.

Detailed inclusion and exclusion criteria were described in the "Materials and Methods" section.

Data extracted from each of the studies were relevant to tumor stage at first staging, details of the endoscopic testing protocol, type and duration of induction treatment, complications occurring during the endoscopic procedures, and confirmatory tests for negative results of endoscopic procedures.

Restricted the analysis to introduction therapy adjusted estimates.

We used the Quality Assessment of Diagnostic Accuracy Studies-2 tool to assess study quality and the potential for bias. Sensitivity analyses were performed subgroup analysis.

We assumed that heterogeneity was present in our data and planned to address it using a random effects model.

Description of methods of meta-analyses, sensitivity analyses and assessment of publication bias are detailed in the methods.

We included 1 box detailing the terms used for database search, 1 flow chart, 1 summary table, and 1 table of outcome analyses.

\section{Figure 1}

Table 1

Table 2

$95 \%$ CIs were presented with all summary estimates 
Brief description of how the criteria were handled in the

Criteria meta-analysis

\begin{tabular}{|c|c|}
\hline \multicolumn{2}{|l|}{ Reporting of discussion should include } \\
\hline$\sqrt{ }$ Quantitative assessment of bias & Sensitivity analyses were discussed according to subgroup analysis. \\
\hline$\sqrt{ }$ Justification for exclusion & We excluded studies that had not meet the eligible criteria. \\
\hline$\sqrt{ }$ Assessment of quality of included studies & $\begin{array}{l}\text { We discussed the results of the sensitivity analyses, and potential reasons } \\
\text { for the observed heterogeneity. }\end{array}$ \\
\hline \multicolumn{2}{|l|}{ Reporting of conclusions should include } \\
\hline$\sqrt{ }$ Consideration of alternative explanations for observed results & $\begin{array}{l}\text { Different chemotherapy agents and various numbers of treatment cycles } \\
\text { were used and some patients received radiation in addition of } \\
\text { chemotherapy. This has the potential of influencing the outcome of } \\
\text { restaging lung cancer. }\end{array}$ \\
\hline$\sqrt{ }$ Generalization of the conclusions & $\begin{array}{l}\text { Endosonography with lymph node sampling is an accurate and safe } \\
\text { technique in mediastinal restaging in patients with lung cancer after } \\
\text { induction treatment. For nondiagnostic results, a further more invasive } \\
\text { approach should be thoroughly considered. }\end{array}$ \\
\hline$\sqrt{ }$ Guidelines for future research & $\begin{array}{l}\text { We recommend future prospective studies on the association between } \\
\text { these variables. }\end{array}$ \\
\hline$\sqrt{ }$ Disclosure of funding source & No funding. \\
\hline
\end{tabular}


TABLE E2. Preferred reporting items for systematic reviews and meta-analysis statement checklist

\begin{tabular}{|c|c|c|c|}
\hline Section/topic & No. & Checklist item & $\begin{array}{l}\text { Reported } \\
\text { on page \# }\end{array}$ \\
\hline \multicolumn{4}{|l|}{ Title } \\
\hline Title & 1 & Identify the report as a systematic review, meta-analysis, or both. & 1 \\
\hline \multicolumn{4}{|l|}{ Abstract } \\
\hline Structured summary & 2 & $\begin{array}{l}\text { Provide a structured summary including, as applicable: background; objectives; data } \\
\text { sources; study eligibility criteria, participants, and interventions; study appraisal and } \\
\text { synthesis methods; results; limitations; conclusions and implications of key findings; } \\
\text { systematic review registration number. }\end{array}$ & 3 \\
\hline \multicolumn{4}{|l|}{ Introduction } \\
\hline Rationale & 3 & Describe the rationale for the review in the context of what is already known. & $5-6$ \\
\hline Objectives & 4 & $\begin{array}{l}\text { Provide an explicit statement of questions being addressed with reference to } \\
\text { participants, interventions, comparisons, outcomes, and study design (PICOS). }\end{array}$ & $5-6$ \\
\hline \multicolumn{4}{|l|}{ Methods } \\
\hline Protocol and registration & 5 & $\begin{array}{l}\text { Indicate if a review protocol exists, if and where it can be accessed (eg, Web address), } \\
\text { and, if available, provide registration information including registration number. }\end{array}$ & 7 \\
\hline Eligibility criteria & 6 & $\begin{array}{l}\text { Specify study characteristics (eg, PICOS, length of follow-up) and report characteristics } \\
\text { (eg, years considered, language, publication status) used as criteria for eligibility, } \\
\text { giving rationale. }\end{array}$ & 7 \\
\hline Information sources & 7 & $\begin{array}{l}\text { Describe all information sources (eg, databases with dates of coverage, contact with } \\
\text { study authors to identify additional studies) in the search and date last searched. }\end{array}$ & 8 \\
\hline Search & 8 & $\begin{array}{l}\text { Present full electronic search strategy for at least one database, including any limits } \\
\text { used, such that it could be repeated. }\end{array}$ & 7 \\
\hline Study selection & 9 & $\begin{array}{l}\text { State the process for selecting studies (ie, screening, eligibility, included in systematic } \\
\text { review, and, if applicable, included in the meta-analysis). }\end{array}$ & 7 \\
\hline Data collection process & 10 & $\begin{array}{l}\text { Describe method of data extraction from reports (eg, piloted forms, independently, in } \\
\text { duplicate) and any processes for obtaining and confirming data from investigators. }\end{array}$ & 8 \\
\hline Data items & 11 & $\begin{array}{l}\text { List and define all variables for which data were sought (eg, PICOS, funding sources) } \\
\text { and any assumptions and simplifications made. }\end{array}$ & 8 \\
\hline $\begin{array}{l}\text { Risk of bias } \\
\quad \text { in individual studies }\end{array}$ & 12 & $\begin{array}{l}\text { Describe methods used for assessing risk of bias of individual studies (including } \\
\text { specification of whether this was done at the study or outcome level), and how this } \\
\text { information is to be used in any data synthesis. }\end{array}$ & $8-9$ \\
\hline Summary measures & 13 & State the principal summary measures (eg, risk ratio, difference in means). & $8-9$ \\
\hline Synthesis of results & 14 & $\begin{array}{l}\text { Describe the methods of handling data and combining results of studies, if done, } \\
\text { including measures of consistency }\left(\mathrm{eg}, \mathrm{I}^{2}\right) \text { for each meta-analysis. }\end{array}$ & $8-9$ \\
\hline Risk of bias across studies & 15 & $\begin{array}{l}\text { Specify any assessment of risk of bias that may affect the cumulative evidence (eg, } \\
\text { publication bias, selective reporting within studies). }\end{array}$ & $8-9$ \\
\hline Additional analyses & 16 & $\begin{array}{l}\text { Describe methods of additional analyses (eg, sensitivity or subgroup analyses, meta- } \\
\text { regression), if done, indicating which were pre-specified. }\end{array}$ & $8-9$ \\
\hline \multicolumn{4}{|l|}{ Results } \\
\hline Study selection & 17 & $\begin{array}{l}\text { Give numbers of studies screened, assessed for eligibility, and included in the review, } \\
\text { with reasons for exclusions at each stage, ideally with a flow diagram. }\end{array}$ & $9-10$ \\
\hline Study characteristics & 18 & $\begin{array}{l}\text { For each study, present characteristics for which data were extracted (eg, study size, } \\
\text { PICOS, follow-up period) and provide the citations. }\end{array}$ & $9-10$ \\
\hline Risk of bias within studies & 19 & $\begin{array}{l}\text { Present data on risk of bias of each study and, if available, any outcome-level } \\
\text { assessment (see Item 12). }\end{array}$ & $10-11$ \\
\hline Results of individual studies & 20 & $\begin{array}{l}\text { For all outcomes considered (benefits or harms), present, for each study: (a) simple } \\
\text { summary data for each intervention group and (b) effect estimates and CIs, ideally } \\
\text { with a forest plot. }\end{array}$ & $10-11$ \\
\hline Synthesis of results & 21 & Present results of each meta-analysis done, including CIs and measures of consistency. & $10-11$ \\
\hline Risk of bias across studies & 22 & Present results of any assessment of risk of bias across studies (see Item 15). & $10-11$ \\
\hline Additional analysis & 23 & $\begin{array}{l}\text { Give results of additional analyses, if done (eg, sensitivity or subgroup analyses, meta- } \\
\text { regression [see Item 16]). }\end{array}$ & $10-11$ \\
\hline
\end{tabular}


TABLE E2. Continued

\begin{tabular}{lcc}
\hline \multicolumn{1}{c}{ Section/topic } & No. & \multicolumn{1}{c}{$\begin{array}{c}\text { Reported } \\
\text { on page \# }\end{array}$} \\
\hline $\begin{array}{l}\text { Discussion } \\
\text { Summary of evidence }\end{array}$ & $24 \quad \begin{array}{c}\text { Summarize the main findings including the strength of evidence for each main outcome; } \\
\text { consider their relevance to key groups (eg, health care providers, users, and policy } \\
\text { makers). } \\
\text { Discuss limitations at study and outcome level (eg, risk of bias), and at review level } \\
\text { (eg, incomplete retrieval of identified research, reporting bias). } \\
\text { Provide a general interpretation of the results in the context of other evidence, and } \\
\text { implications for future research. }\end{array}$ \\
$\begin{array}{l}\text { Conclusions } \\
\text { Funding }\end{array}$ & $26 \quad \begin{array}{c}\text { Describe sources of funding for the systematic review and other support (eg, supply of } \\
\text { data); role of funders for the systematic review. }\end{array}$ \\
\hline PICOS, Patient, intervention, comparison, outcome, study design. & 14
\end{tabular}


TABLE E3. Quality assessment of Diagnostic Accuracy Studies-2 tool for quality assessment of the included studies

\begin{tabular}{|c|c|c|c|c|c|c|c|c|c|c|c|c|c|c|c|c|c|c|}
\hline $\begin{array}{l}\text { Study } \\
\text { (Year) }\end{array}$ & $\begin{array}{c}\text { DOM } \\
1 A 1\end{array}$ & $\begin{array}{c}\text { DOM } \\
1 \mathrm{A2}\end{array}$ & $\begin{array}{c}\text { DOM } \\
1 \mathrm{~A} 3\end{array}$ & $\begin{array}{c}\text { DOM } \\
1 \mathrm{A4}\end{array}$ & $\begin{array}{c}\text { DOM } \\
\text { 1B }\end{array}$ & $\begin{array}{c}\text { DOM } \\
2 A 1\end{array}$ & $\begin{array}{c}\text { DOM } \\
2 \mathrm{~A} 2\end{array}$ & $\begin{array}{c}\text { DOM } \\
2 \mathrm{A3}\end{array}$ & $\begin{array}{c}\text { DOM } \\
\text { 2B }\end{array}$ & $\begin{array}{c}\text { DOM } \\
\text { 3A1 }\end{array}$ & $\begin{array}{c}\text { DOM } \\
\text { 3A2 }\end{array}$ & $\begin{array}{c}\text { DOM } \\
\mathbf{3 A 3}\end{array}$ & $\begin{array}{c}\text { DOM } \\
\text { 3B }\end{array}$ & $\begin{array}{c}\text { DOM } \\
\text { 4A1 }\end{array}$ & $\begin{array}{c}\text { DOM } \\
4 \mathrm{~A} 2\end{array}$ & $\begin{array}{c}\text { DOM } \\
4 A 3\end{array}$ & $\begin{array}{c}\text { DOM } \\
4 A 4\end{array}$ & $\begin{array}{c}\text { DOM } \\
4 A 5\end{array}$ \\
\hline $\begin{array}{l}\text { Annema } \\
\text { (2003) }\end{array}$ & $\mathrm{U}$ & $\mathrm{Y}$ & $Y$ & $\mathrm{H}$ & $\mathrm{L}$ & $Y$ & $\mathrm{Y}$ & $\mathrm{L}$ & $\mathrm{L}$ & $\mathrm{Y}$ & $\mathrm{Y}$ & $\mathrm{L}$ & $\mathrm{L}$ & $Y$ & $Y$ & $\mathrm{Y}$ & $Y$ & $\mathrm{~L}$ \\
\hline $\begin{array}{l}\text { Varadarajulu } \\
\text { (2006) }\end{array}$ & $Y$ & $\mathrm{Y}$ & $\mathrm{Y}$ & $\mathrm{L}$ & $\mathrm{L}$ & $Y$ & $\mathrm{Y}$ & $\mathrm{L}$ & $\mathrm{L}$ & $\mathrm{Y}$ & $Y$ & $\mathrm{~L}$ & $\mathrm{~L}$ & $\mathrm{Y}$ & $\mathrm{Y}$ & $\mathrm{Y}$ & $\mathrm{Y}$ & $\mathrm{L}$ \\
\hline $\begin{array}{l}\text { Herth } \\
\quad(2008)\end{array}$ & $\mathrm{U}$ & $\mathrm{Y}$ & $\mathrm{Y}$ & $\mathrm{H}$ & $\mathrm{L}$ & $\mathrm{Y}$ & $\mathrm{Y}$ & $\mathrm{L}$ & $\mathrm{L}$ & $\mathrm{Y}$ & $\mathrm{Y}$ & $\mathrm{L}$ & $\mathrm{L}$ & $\mathrm{Y}$ & $\mathrm{Y}$ & $\mathrm{Y}$ & $\mathrm{Y}$ & $\mathrm{L}$ \\
\hline $\begin{array}{l}\text { Stigt } \\
\quad(2009)\end{array}$ & $\mathrm{U}$ & $Y$ & $\mathrm{Y}$ & $\mathrm{H}$ & $\mathrm{L}$ & $Y$ & $\mathrm{Y}$ & $\mathrm{L}$ & $\mathrm{L}$ & $\mathrm{Y}$ & $\mathrm{Y}$ & $\mathrm{L}$ & $\mathrm{L}$ & $\mathrm{Y}$ & $\mathrm{Y}$ & $\mathrm{Y}$ & $\mathrm{Y}$ & $\mathrm{L}$ \\
\hline $\begin{array}{l}\text { Szlubowski } \\
\text { (2010) }\end{array}$ & $\mathrm{U}$ & $\mathrm{Y}$ & $\mathrm{Y}$ & $\mathrm{U}$ & $\mathrm{L}$ & $\mathrm{Y}$ & $\mathrm{Y}$ & $\mathrm{L}$ & $\mathrm{L}$ & $\mathrm{Y}$ & $\mathrm{Y}$ & $\mathrm{L}$ & $\mathrm{L}$ & $\mathrm{Y}$ & $\mathrm{Y}$ & $\mathrm{Y}$ & $\mathrm{Y}$ & $\mathrm{L}$ \\
\hline $\begin{array}{l}\text { von Bartheld } \\
\text { (2011) }\end{array}$ & $\mathrm{Y}$ & $\mathrm{Y}$ & $Y$ & L & $\mathrm{L}$ & $Y$ & $Y$ & $\mathrm{~L}$ & $\mathrm{~L}$ & $\mathrm{Y}$ & $\mathrm{Y}$ & $\mathrm{L}$ & $\mathrm{L}$ & $Y$ & $\mathrm{Y}$ & $Y$ & $\mathrm{~N}$ & $\mathrm{~L}$ \\
\hline $\begin{array}{r}\text { Zielinski } \\
(2013)\end{array}$ & $\mathrm{Y}$ & $\mathrm{Y}$ & Y & $\mathrm{L}$ & $\mathrm{L}$ & $\mathrm{Y}$ & $\mathrm{Y}$ & $\mathrm{L}$ & $\mathrm{L}$ & $\mathrm{Y}$ & $\mathrm{Y}$ & $\mathrm{L}$ & $\mathrm{L}$ & $\mathrm{Y}$ & $\mathrm{Y}$ & $\mathrm{Y}$ & $\mathrm{N}$ & L \\
\hline $\begin{array}{c}\text { Szlubowski } \\
\text { (2014) }\end{array}$ & $\mathrm{U}$ & $Y$ & $\mathrm{Y}$ & $\mathrm{U}$ & $\mathrm{L}$ & $\mathrm{Y}$ & $Y$ & $\mathrm{~L}$ & $\mathrm{~L}$ & $\mathrm{Y}$ & $\mathrm{Y}$ & $\mathrm{L}$ & $\mathrm{L}$ & $\mathrm{Y}$ & $\mathrm{Y}$ & $\mathrm{Y}$ & $\mathrm{N}$ & $\mathrm{L}$ \\
\hline $\begin{array}{c}\text { Cetinkaya } \\
\text { (2017) }\end{array}$ & $\mathrm{U}$ & $\mathrm{Y}$ & $\mathrm{Y}$ & $\mathrm{U}$ & $\mathrm{L}$ & $\mathrm{Y}$ & $\mathrm{Y}$ & $\mathrm{L}$ & $\mathrm{L}$ & $\mathrm{Y}$ & $\mathrm{Y}$ & $\mathrm{L}$ & $\mathrm{L}$ & $\mathrm{Y}$ & $\mathrm{Y}$ & $\mathrm{Y}$ & $\mathrm{N}$ & $\mathrm{L}$ \\
\hline $\begin{array}{l}\text { Yoon } \\
\quad(2018)\end{array}$ & $\mathrm{U}$ & $Y$ & $\mathrm{Y}$ & $\mathrm{U}$ & $\mathrm{L}$ & $\mathrm{Y}$ & $\mathrm{Y}$ & $\mathrm{L}$ & L & $\mathrm{Y}$ & $\mathrm{Y}$ & $\mathrm{L}$ & $\mathrm{L}$ & $\mathrm{Y}$ & $\mathrm{Y}$ & $Y$ & $\mathrm{Y}$ & $\mathrm{L}$ \\
\hline $\begin{array}{l}D O M I A 1 \text {, Cons } \\
\text { included patient } \\
\text { have introduced } \\
\text { from index test } \\
D O M 4 A 1 \text {, appr } \\
D O M 4 A 4 \text {, all pa }\end{array}$ & $\begin{array}{l}\text { itive or ra } \\
\text { o not mat } \\
\text { s; } D O M 21 \\
\text { ults; } D O 1 \\
\text { iate inter } \\
\text { nts includ }\end{array}$ & $\begin{array}{l}\text { om samp } \\
\text { the revie } \\
\text { concern th } \\
\text { A3, coulc } \\
1 \text { between } \\
\text { in the an }\end{array}$ & $\begin{array}{l}\text { of patient } \\
\text { question; } \\
\text { index tes } \\
\text { he referes } \\
\text { index test } \\
\text { ysis; } D O N\end{array}$ & $\begin{array}{l}\text { enrolled; } \\
\text { OM2A1, i } \\
\text { onduct or } \\
\text { e standare } \\
\text { ind refere } \\
\text { A5, could }\end{array}$ & $\begin{array}{l}M 1 A 2, \\
\text { ex test r } \\
\text { erpretati } \\
\text { ts condu } \\
\text { standa } \\
\text { patient }\end{array}$ & $\begin{array}{l}\text { se-control } \\
\text { lts interp } \\
\text { differ fro } \\
\text { or its in } \\
\text {; DOM4 } \\
\text { ow have i }\end{array}$ & $\begin{array}{l}\text { esign avo } \\
\text { ed witho } \\
\text { review q } \\
\text { pretation } \\
\text { all incl } \\
\text { oduced b }\end{array}$ & $\begin{array}{l}\text { ed; } D O M \\
\text { knowleds } \\
\text { stion; } D O \text {. } \\
\text { ave introc } \\
\text { ed specin } \\
\text { s; } U \text {, uncl }\end{array}$ & $\begin{array}{l}3 \text {, study } \\
\text { of results } \\
3 A 1, \text { refer } \\
\text { ced bias; } \\
\text { ns receiv } \\
\text { r; } Y \text {, yes; }\end{array}$ & $\begin{array}{l}\text { oided in } \\
\text { f referen } \\
\text { ce stand } \\
O M 3 B \text {, } \\
\text { the ref } \\
\text { high; } L\end{array}$ & $\begin{array}{l}\text { ropriate ex } \\
\text { tandard; } \\
\text { correctly } \\
\text { cern that } \\
\text { nce stand } \\
N ; N \text {, no. }\end{array}$ & $\begin{array}{l}\text { lusions; } D \\
O M 2 A 2, \mathrm{p} \\
\text { Issifies cor } \\
\text { rget condi } \\
\text { d;DOM4 }\end{array}$ & $\begin{array}{l}M 1 A 4, \text { se } \\
\text { specified } \\
\text { ition; } D O \\
\text { on define } \\
3 \text {, all inc }\end{array}$ & $\begin{array}{l}\text { ction of } p \\
\text { reshold u. } \\
3 A 2 \text {, refer } \\
\text { by refere } \\
\text { ded speci }\end{array}$ & $\begin{array}{l}\text { ients int } \\
\text { d; } D O M \\
\text { ice stand } \\
\text { e standa } \\
\text { ens rece }\end{array}$ & $\begin{array}{l}\text { Iced bias } \\
\text {, could th } \\
\text { results in } \\
\text { loes not } \\
d \text { the sal }\end{array}$ & $\begin{array}{l}O M 1 B, \\
\text { conduct } \\
\text { preted inc } \\
\text { tch revie } \\
\text { referenc }\end{array}$ & $\begin{array}{l}\text { icern that } \\
\text { index test } \\
\text { pendently } \\
\text { question; } \\
\text { standard; }\end{array}$ \\
\hline
\end{tabular}

